\title{
Intellectual Capital Approach for a Better Corporate Governance of Sharia Banking
}

\author{
Hadi Purnomo \\ School of Business, Bogor Agricultural University (IPB) \\ purnomohd@yahoo.co.id
}

Arya Hadi Dharmawan

Faculty of Human Ecology, Bogor Agricultural University (IPB)

Aida Vitayala Hubeis

Faculty of Human Ecology, Bogor Agricultural University (IPB)

Irfan Syauqi Beik

Faculty of Economics and Management, Bogor Agricultural University (IPB)

Abstract

The Implementation of corporate governance of sharia banking in Indonesia has not been effective. Sharia banking in Indonesia do not yet have a standard of sharia governance framework as a guideline for the implementation of corporate governance. This study was conducted to analyze the implementation of corporate governance and intellectual capital condition of sharia banks, and to develop a more effective model of corporate governance by using the approach of intellectual capital. The data came from the annual financial statements of 12 Sharia Commercial Banks (BUS), and information based on answers to questionnaires by sharia banking practitioners. The results of this study indicate that the condition of intellectual capital contributes to the performance of BUS, while the implementation of corporate governance does not contribute significantly. However, corporate governance and intellectual capital contribute simultaneously to the performance of BUS. The implication based on finding indicated that intellectual capital can be 
Keywords:

corporate

governance;

intellectual capital; sharia commercial bank (BUS); sharia governance framework developed as a basic for implementation of corporate governance in sharia banking. This is a new approach because the concept of corporate governance is generally more focused on rules and policies, it is rare to consider a holistic approach and align with the conditions of the company's intellectual capital. 


\section{INTRODUCTION}

In line with the sharia economic growth globally, sharia banking in Indonesia is also growing rapidly until 2014, well above the average growth of conventional bank assets. However, the role of sharia banking is not significant because until 2016 only has total assets of Rp366 trillion or with a market share of only $5.12 \%$. So far, the overall financial performance of sharia banks is still lower than conventional banking performance.

According to Financial Service Authority (OJK) report (2017), the sharia bank in Indonesia still faces the problem of high non-performing financing (NPF) portfolio, poor supervision and risk management system. This is indicated by the discovery of some operational and internal fraud irregularities in Islamic banks. The condition shows that the implementation of governance in Islamic banks is still weak. As an institution of trust, sharia banks should be able to ensure the company's operations run in accordance with good corporate governance and in line with prevailing rules and regulations.

Many studies have shown that good corporate governance positively affects the company's performance. Wellmanaged companies are becoming more credible, making it easier for companies to get loans from financial institutions and get lower interest rates than corporations whose governance is worse (Mishra and Mohanty, 2014). According to Carrel (2007), in addition to developing a good corporate governance system, companies must be able to cope with change and take full advantage of intangible resources to improve performance and gain competitive advantage.

The CG issue for sharia banks is relatively new. According to Dusuki (2006), as an organization governed by Islamic sharia principles, Islamic financial institutions must strictly observe and fulfill their obligations as determined by Islamic sharia law. The concept of sharia financial system is actually structured on the basis of solid governance principles. In the practice of sharia financial system, good corporate governance is not unfamiliar, because for a Muslim all life activities must refer to the rules set in the Qur' an and al Hadith.

Implementation of corporate governance of the banking industry in Indonesia refers to Bank Indonesia (BI) regulation. In accordance with Bank Indonesia Circular Letter SE BI No.15/15/ DPNP/2013 on the Implementation of Good 
Corporate Governance for Commercial Banks, BI enhances the Bank Rating method using Risk Based Bank Rating (RBBR) either individually or consolidated between others include an assessment of GCG factors. In particular, the implementation of risk-based corporate governance for sharia banking is governed by the Financial Services Authority Regulation POJK No.8/ POJK.03/2014 on the Rating of the Health of Sharia Commercial Banks and Sharia Business Units.

Research on Intellectual Capital (IC) in Indonesia is relatively new, research on this topic began to develop early in 2005 (Ulum, 2013). Companies in Indonesia have not implemented and optimized the company's intellectual capital. Unlike in Indonesia, research on IC in the banking industry in the world has been widely done with a more varied methodology (Santoso, 2011).

In the era of knowledge-base economy has been identified that the success of a company depends on the company's ability to create the uniqueness of intangible assets and convert them into value (Andriessen, 2001). Yallwe and Buscemi (2014) argue, intangible assets or intellectual assets are non-selfsufficient assets such as assets such as factories, machinery and equipment. The Company combines all assets, intellectual assets and tangible assets, to generate cash flow and improve efficiency and effectiveness. Several studies have also shown that intellectual assets can increase labor productivity (Yallwe and Buscemi, 2014).

Research on corporate governance model that related to the implementation of intellectual capital is rare to be done (Keenan and Aggestam, 2001). Although according to Holland (2003), preliminary studies have shown that IC is affect corporate governance. Several studies have shown the implementation of the linkage between governance and IC impacts the company's performance (Arifin, 2016; Earnest and Sofian, 2013; Hidalgo et al., 2011; Saffiedine et al., 2009; Li et al., 2008).

Previous studies generally use primary data sourced from the company's external report. The concept is developed by incorporating the concept of sharia corporate governance and intellectual capital governance to establish Islamic governance. The method of the research is better than previous studies because it also uses primary data and secondary data reinforced by in-depth interview. Strengthening the corporate governance 
system for sharia banking by using intellectual capital is a new approach as well as novelty of this research. This is in line with the opinion of Lukviarman (2016), that the development of research toward non-mainstream methodology increasingly enriched CG field research. The research enrichment approach is expected to encourage developing and experimenting through the use of new methodologies, as well as developing research coverage.

The corporate governance system based on intellectual capital can be an input for the Financial Services Authority (OJK) as the holder of authority to immediately create and develop a sharia governance framework (SGF) in accordance with the condition of sharia banking in Indonesia. The results of this study can be used by the Islamic finance industry, especially sharia banking to improve the implementation of better sharia banking governance so as to improve the competitiveness and value of the company.

\section{LITERATURE STUDY Definition and Measurement CG}

The most frequently cited definition of corporate governance is that given by Shleifer and Vishny (Shleifer and Vishny, 1997) that define CG as governance with respect to the ways in which financiers who supply finance to firms assure themselves of a return on their investment. According to Bouheni (2016), the term corporate governance can be interpreted narrowly or broadly, related to the perspective of shareholders and stakeholder orientation. The narrow definition of CG is to pay particular attention to the relationship between corporate managers, the Board of Directors and shareholders, but may also include corporate relationships with stakeholders and communities. Broader definition, CG includes a combination of laws, rules and practices that enable companies to attract capital, efficiency of performance, generate profits and bring legal obligations to public expectations.

Mallin (2013), also stressed that an important aspect of CG is whether the company operates within the framework of shareholders whose primary focus is on maintaining or increasing shareholder value. Or do take a broader stakeholder approach, emphasizing the interests of diverse groups, such as employees, credit providers, suppliers, customers, and the public. 
The definition of governance in Indonesia is also quite diverse. Corporate governance has been the concern of corporations and the Indonesian government since the 1997 monetary crisis. Based on the Decree of the Minister of State Owned Enterprises (BUMN) No. KEP-117 /M-MBU/2002, defines corporate governance (CG) as a process of the structure used by SOE (State Owned Enterprises) organs to enhance business success and corporate accountability in order to realize shareholder value in the long term by taking into account the interests of other stakeholders based on legislation and ethics. Meanwhile, according to the National Committee on Governance Policy (KNKG), good corporate governance is one of the pillars of the market economy system. Corporate governance is closely related to the trust of both companies that implement it and the business climate in a country (KNKG, 2011).

Lessambo (2014) describes the CG encompassing transparency, openness, and accountability, as well as the elimination of collusion, corruption, and nepotism, which is a basic requirement for economic growth. Corporate governance ensures that firms use resources more efficiently, protect minority shareholders, lead to better decision making, and improve relationships with workers, creditors and other stakeholders. Furthermore, CG influences how company goals are defined and achieved, how risks are monitored and assessed, and how performance is optimized.

Measurement of good governance implementation for sharia banking refers to Circular Letter of Bank Indonesia SE BI: No.12/13/DPbS/2010 and Regulation of Finance Service Authority POJK: No.8/POJK.03/2014 on the Rating of the Health of Sharia Commercial Banks and Sharia Business Units. According to SE BI: No.12/13/DPbS/2010, BUS and UUS shall periodically conduct a comprehensive self assessment of the adequacy of GCG implementation, taking into account 11 factors with coverage as follows:

1. Four factors that discuss the duties, and functions of the Board of Commissioners, Board of Directors, Sharia Supervisory Board (DPS) and the Committee

2. Five factors that address conflict of interest, compliance function, audit and transparency of financial and non financial reporting

3. One factor discussing sharia compliance against the collection 
and distribution of funds

4. One factor that discusses the maximum limit of fund disbursement (BMPD)

\section{Definition and the role of IC in the Company}

The concept of intellectual capital (IC) is very complex and diverse, so there are many disagreements about the definition of IC is, elements, and IC structures that play a role in the organization. Some researchers define IC is as resources, some other researchers believe that IC are intangible assets, but some researchers view IC is as knowledge (Lapina, 2016).

There are several different views on the components that make up the IC, but basically the thinking is the same. For example, according to the Scandia Navigator, the IC is divided into human capital and structural, then structural capital is divided into customer capital and organizational capital, and organizational capital is subdivided into innovation and process capital (Bratianu, 2008). IC has emerged as an umbrella concept covering all images of intangible assets, ie human, relational and structural (Carlucci and Lerro, 2010).

According to Meritum (2002), the most common and widely agreed IC structure has three main elements: Human Capital (HC), Structure Capital (SC) and Relational Capital (RC). HC describes the knowledge possessed by a company's human resources, including skills, knowledge, and abilities. The competency will be lost when the human resources are out of the company. SC is defined as the knowledge that will remain in the company, even though the HR is out of the company. Examples are system operating procedure (SOP), culture, data base, knowledge center, intellectual property right, brand and others. RC describes resources related to the company's relationships with external parties and all stakeholders (investors, creditors, customers, suppliers and etc).

Many economists have proved that in the 21st century the value of the firm will be shaped primarily by intangible assets (Edvinsson and Malone, 1997; Sveiby, 1997). In addition, companies that rely on intensive knowledge, the management of intangible assets becomes very important. This is indicated by the high ratio between market value and book value of the company (Andriessen, 2004). 
The role of intangible assets in business and finance is becoming increasingly important. Kaplan and Norton (2004) compared the book value of total assets to the market value of the firm, they found that the value of intellectual assets was about $70 \%$ of the market value of the company in 2002, up from about 40 percent in 1982. Based on data from 1978 to 2004, the asset base index of Standars and Poors (S \& P) 500 has changed radically from $95 \%$ in tangible assets to $85 \%$ in the form of intangible assets. Value of intangible asset is two to three times higher than traditional tangible physical and financial assets (Moore and Craig, 2008).

The phenomenon of increasing market cap value is extraordinary happened also in Indonesia. One of the newest on line transportation services company established in early 2015 has market capitalization of Rp17 trillion in 2016, which is higher than the market capitalization of Garuda Indonesia of Rp12.3 trillion (TechCrunch-Wallstreet Journal, 2016).

Haniffa (2013) asserts that IC have a very significant impact on the performance of corporations from Islamic Financial Institutions (LKS). This makes the management of intellectual capital and intangible assets very important to be developed as a basis for creating competitive advantage for a bank (Chen et al., 2014).

\section{Intellectual Capital Measurement}

The VAIC TM model (Value Added Intellectual Capital Coefficient) is the most popular used including for measuring the IC of a bank. VAIC is the first coefficient developed by Ante Pulic (Pulic, 1998) and further improved by Manfred Bornemann (Bornemann, 1999). VAIC provides a way to measure the efficiency of a company's value creation as a result of the use of intellectual capital by using basic financial data (Shiu, 2006). Other models that are also quite widely applied in addition to VAIC TM are Skandia Navigator, Intangible Assets Monitor, Value Explorer, and others (Santoso, 2011).

Santoso (2011), using the VAIC TM model calculation proves that intellectual capital has a moderate to positive relationship to the financial performance of the Indonesian banking industry. These results are consistent with research conducted by Shih, Chang, and Lin (2010) on banks in Taiwan, and studies conducted by Kamukama, Ahiauzu, and Ntayi (2010) at a microfinance institution in Uganda.

Ulum (2013) has developed a performance measurement 
model for sharia banking IC in Indonesia, iB-VAIC TM. This model was created by modifying accounting accounts on the VAIC TM Pulic model, thus being in line with Islamic banking finance activities. However, this model still refers to the VAIC TM Pulic calculation model. Previously, Ulum (2007) has proven that IC has a positive influence on financial performance of banks that have become public companies.

\section{RESEARCH METHODOLOGY Data}

This research uses primary data and secondary data. Primary data were obtained from questionnaires and in depth interviews to sharia banking practitioners, while secondary data were obtained from BUS financial statements. The number of respondents collected was 117 respondents. All respondents are sharia banking practitioners who are at the lowest level are manager level, and they have experience working in Sharia Commercial Bank (UUS) and Sharia Business Unit (UUS) for more than five years.

The position of respondents in sharia banks are dominated by respondents with senior management positions ie Head Division/Group Head/GM/Head of UUS (29.6\%), Head of Department $(17.6 \%)$, and the rest of the respondents spread evenly from Branch Managers, Regional Managers, Directors, Commissioners and Sharia Supervisory Board (DPS). Based on these data, respondents are policy holders and have strategic activities in sharia banking.

The shareholder of the company where the respondents work are quite varied. Based on the questionnaires, the majority share ownership of the company where the respondent works is owned by the BUMN Bank is $37.4 \%$, the National Private Bank is $23.4 \%$, the Regional Development Bank is $12.1 \%$ and the Foreign Private Bank is $11.2 \%$.

Furthermore, the secondary data used in this study is to use annual financial report data from 12 BUS, as shown in Table 1 . The data used sourced from the financial statements of 20162017, obtained from the website of each bank. 
Table 1 List of Sharia Commercial Banks

\begin{tabular}{llcr}
\hline \multirow{2}{*}{ Code } & \multirow{2}{*}{ Sharia Commercial Bank } & \multicolumn{2}{c}{ Asset (IDR Mio) } \\
\cline { 3 - 4 } & & 2016 & 2017 \\
\hline BSM & Bank Syariah Mandiri & 78.832 & 87.940 \\
BMI & Bank Muamalat Indonesia & 55.786 & 61.786 \\
BNIS & BNI Syariah & 28.314 & 34.828 \\
BRIS & BRI Syariah & 27.687 & 31.543 \\
PNBS & Bank Panin Syariah & 8.758 & 8.629 \\
BMS & Bank Mega Syariah & 6.135 & 7.013 \\
BTPNS & BTPN Syariah & 7.323 & 9.157 \\
BSB & Bank Syariah Bukopin & 7.020 & 7.257 \\
BCAS & BCA Syariah & 4.996 & 5.961 \\
BJBS & BJB Syariah & 7.442 & 7.714 \\
MayBS & Maybank Syariah & 1.370 & 1.414 \\
BVIS & Bank Victoria Syariah & 1.621 & 2.005 \\
\hline
\end{tabular}

Sources: Annual report of BUS 2016-2017

\section{Analysis Method}

This study uses two stages of analysis, the first stage is to analyze the real conditions of implementation of coporate governance and intellectual capital condition of sharia commercial banks. The first phase analysis is using path analysis, IC calculation using VAIC model and ROA calculation to see BUS performance. The second stage is to conduct situational analysis, which aims to know the expectations of sharia banking practitioners on the implementation of more effective Islamic banking governance. The second phase analysis is situational analysis by using descriptive data analysis from questionnaire and in depth interview. To obtain a more effective system of governance implementation, this study then proceeded to use a gap analysis between the expectations of sharia banking practitioners based on the current situation with the real conditions of corporate governance.

The data on the implementation of corporate governance is obtained from the annual report of GCG self-assessment of each BUS. The Bank conducts Self-assessment using predetermined working papers, then BUS may assign a composite rating pursuant to SE Bank Indonesia No.12/13/DPbS/2010. 
The IC BUS condition is calculated by using the iBVAIC TM approach developed by Ulum (2013), which is the development of the Pulic model IC calculation ie VAIC TM (Pulic, 1998). Ulum's final formula (2013) in calculating iB-VAIC TM is:

$$
\text { iB-VAIC }^{\mathrm{TM}}=\mathrm{iB}-\mathrm{VACA}+\mathrm{iB}-\mathrm{VAHU}+\mathrm{iB}-\mathrm{STVA}
$$

Stages of IC calculation using iB-VAIC TM approach (Ulum, 2013) as shown in Table 2.

Table 2 Stages of IC calculation

\begin{tabular}{|c|c|c|c|}
\hline Steps & Variable & Formulation & Notes \\
\hline 1 & $\begin{array}{l}\mathrm{iB}-\mathrm{VA} \\
\text { (iB Value Added) }\end{array}$ & \multicolumn{2}{|c|}{$\begin{aligned} & \mathrm{OP}+\mathrm{EC}+\mathrm{D}+\mathrm{A} \text { OP: } \text { operating profit } \\
& \text { EC: } \text { employee cost } ; \\
& \text { D: depreciation; } \\
& \text { A:Amortization }\end{aligned}$} \\
\hline 2 & $\begin{array}{l}\text { iB-VACA } \\
\text { (iB Value Added Capital Employed) }\end{array}$ & $\mathrm{VA} / \mathrm{CE}$ & $\begin{array}{l}\text { VA: iB value added; } \\
\text { CE: Capital employed } \\
\text { (= total ekuitas) }\end{array}$ \\
\hline 3 & $\begin{array}{l}\text { iB-VAHU } \\
\text { (iB Value Added Human Capital) }\end{array}$ & $\mathrm{VA} / \mathrm{HC}$ & $\begin{array}{l}\text { VA: iB value added; } \\
\text { HC: human capital } \\
\text { cost }(=\mathrm{CE})\end{array}$ \\
\hline 4 & $\begin{array}{l}\text { iB-STVA } \\
\text { (iB Structural Capital Value Added) }\end{array}$ & $\mathrm{SC} / \mathrm{VA}$ & $\begin{array}{l}\text { SC: structural capital } \\
\text { (= iB-VA - HC); } \\
\text { VA: iB value added }\end{array}$ \\
\hline 5 & iB-VAICTM $^{\text {TM }}$ & $=\mathrm{iB}-\mathrm{VACA}+$ & 3-VAHU + iB-STVA \\
\hline
\end{tabular}

Source: Ulum (2013)

In this research the performance of BUS is represented by ROA (Return On Asset), which reflects the business profit and the efficiency of the company in the utilization of total assets (Chen et al., 2014). ROA is calculated with the formula:

$$
\text { ROA= Net Profit : Total Assets }
$$

Path analysis is used to see the contribution of IC and CG to BUS performance. The data analyzed are Intellectual Capital (X1), Corporate Governance (X2) and Return On Assets $(\mathrm{Y})$. The path analysis technique is used to test the contribution contribution by path coefficient on each path diagram of the causal relationship between variables $\mathrm{X} 1$ and $\mathrm{X} 2$ to $\mathrm{Y}$. Correlation 
and regression analysis is the basis of path coefficient calculation (Riduan and Kuncoro, 2008).

\section{RESULT AND DISCUSSION}

\section{Assessment of IC, CG and Performance of Sharia Commercial Banks}

IC rating refers to the criteria submitted by Ulum (2013), CG rating is in accordance with Bank Indonesia SE No.1/13/ $\mathrm{DPbS} / 2010$. Furthermore, the ROA rating refers to the BI SE No.6/23/DPNP in 2004. Summary of IC, CG and ROA rating as shown in Table 3.

\begin{tabular}{|c|c|c|c|c|c|}
\hline \multicolumn{2}{|c|}{ Intellectual Capital } & \multicolumn{2}{|c|}{ Corporate Governance } & \multicolumn{2}{|c|}{ Renturn on Assets } \\
\hline Score & Category & Composit Score & Category & Score & Category \\
\hline$>3$ & Top Performer & $\mathrm{NK}<1,5$ & Outstanding & $>1,5 \%$ & Strong \\
\hline $2,00-2,99$ & Good Performer & $1,5 \leq \mathrm{NK}<2,5$ & Best & $1,26 \%-1,50 \%$ & Satisfactory \\
\hline $1,50-1,99$ & Common Performer & $2,5 \leq \mathrm{NK}<3,5$ & Good & $0,51 \%-1,25 \%$ & Fair \\
\hline \multirow[t]{2}{*}{$<1,5$} & Bad Performer & $3,5 \leq \mathrm{NK}<4,5$ & Poor & $0,1 \%-0,50 \%$ & Marginal \\
\hline & & $4,5 \leq \mathrm{NK} \leq 5$ & Fail & $\leq 0$ & Unsatisfactory \\
\hline
\end{tabular}

Based on the calculation, the results obtained from the assessment of IC, CG and the performance of sharia commercial banks for the period of 2016. The calculation results are then converted into respective rankings as shown in Table 3. After conversion, then obtained the rating of IC, CG and ROA from Bank Sharia General as shown in Table 4.

Table 4 Rating of IC, CG and ROA of BUS

\begin{tabular}{llll}
\hline \multicolumn{1}{c}{ BANKS } & $\begin{array}{c}\text { INTELLECTUAL } \\
\text { CAPITAL }\end{array}$ & $\begin{array}{l}\text { CORPORATE } \\
\text { GOVERNANCE }\end{array}$ & $\begin{array}{c}\text { PERFORMANCE } \\
\text { (ROA) }\end{array}$ \\
\hline BSM & Top Performer & Outstanding & Fair \\
BMI & Top Performer & Best & Marginal \\
BNIS & Top Performer & Best & Satisfactory \\
BRIS & Top Performer & Best & Fair \\
PNBS & Common Performer & Best & Marginal \\
BMS & Top Performer & Best & Strong \\
BTPNS & Top Performer & Best & Strong \\
BSB & Top Performer & Best & Fair \\
BCAS & Top Performer & Outstanding & Fair \\
BJBS & Bad Performer & Good & Unsatisfactory \\
MayBS & Bad Performer & Good & Unsatisfactory \\
BVIS & Bad Performer & Best & Unsatisfactory \\
\hline
\end{tabular}

Source: Data is processed from BUS Annual Report 2016 
Based on the data in Table 4, itcan be seen that the condition of intellectual capital in 2016 overall is very good, from 12 BUS there are eight BUS classified in top performer category, one bank in common performer category and three banks are in bad performer category. Implementation of corporate governance overall is the best, because there are two banks are in outstanding category, eight banks are in best category and two banks are in good category. In terms of performance, there are only two banks are in strong category, one bank is in satisfactory category, four banks are in fair category, two banks are in marginal category and three banks are in unsatisfactory category

\section{Relationship of IC Conditions, CG Implementation, and Sharia Banking Performance}

The relationship and contribution of IC and CG to BUS performance is processed with SPSS program. Then obtained an empirical causal relationship diagram between IC (X1) and CG $(\mathrm{X} 2)$ on ROA (Y), as shown in Figure 1.

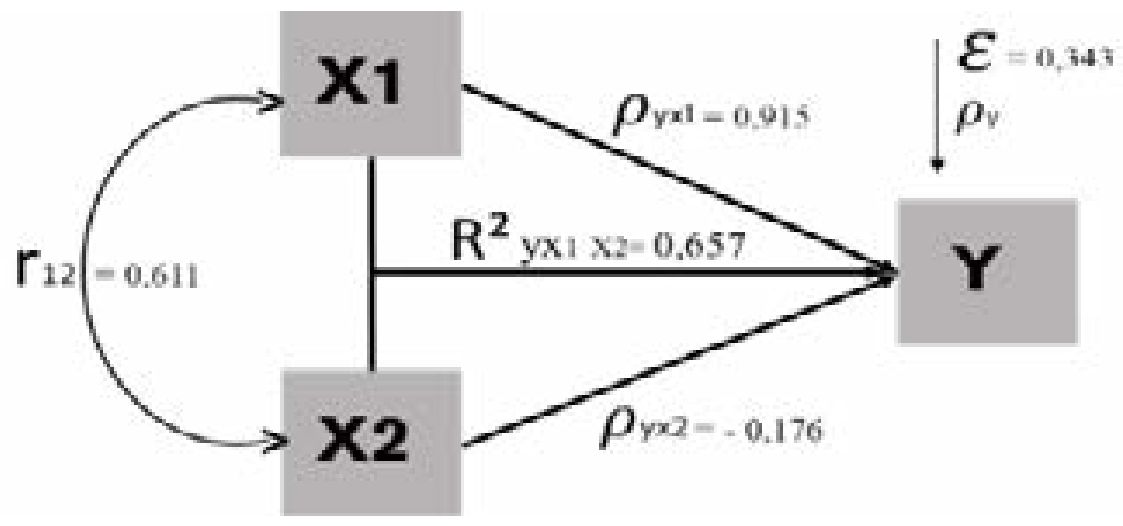

Figure 1 Relationship of IC structure, and CG to ROA

The empirical causal relation framework between $\mathrm{X} 1$ and $\mathrm{X} 2$ to $\mathrm{Y}$ can be made through the following structural equations:

$$
\begin{aligned}
Y & =\rho y x 1 X 1+\rho y \times 2 \times 2+\rho y \varepsilon \\
& =0.915 X 1-0.176 \times 2+\rho y \varepsilon \\
& =0.915 X 1-0.176 \times 2+0.343 \varepsilon
\end{aligned}
$$

The result of calculation of structure path analysis gives information that: 
1. Intellectual capital (X1) has contributed directly and influenced the performance of Islamic banks $(\mathrm{Y})$ is equal to $0.915^{2}=$ 0.837 or $83.7 \%$.

2. Corporate governance $(X 2)$ did not contribute directly and did not affect the performance of Syariah Bank with contribution $-0.176^{2}=0,031$ or only $3.1 \%$ with negative direction.

3. The amount of contribution of intellectual capital (X1) and governance $(X 2)$ simultaneously influence directly affect the performance of Syariah Bank $(Y)$ is $0.657=65.7 \%$. The rest of $34.3 \%$ is influenced by other factors that can not be explained in the study

The results of this study indicate that intellectual capital contributes $83.7 \%$ directly to BUS performance, while corporate governance does not contribute directly to the performance of BUS. However, CG and IC were able to give simultaneous direct contribution of $65.7 \%$ to BUS performance. These results are different from some existing studies that show a close relationship between CG and IC. The close relationship between CG and IC can be seen in some literature stating that CG has influenced the disclosure of capital capital information ( $\mathrm{Li}$ et al 2008; Hidalgo et al., 2011; Arifin, 2016). Santoso (2011), also shows that IC has a positive effect on banking performance in Indonesia.

IC condition in sharia banks that correlate significantly with the performance of BUS shows the role of human factor that is still very dominant as the main component of intellectual capital in planning, organizing, executing and monitoring business plans. In contrast, CG implementation does not contribute to performance, because the principles of good governance are only seen as written rules and policies. This condition is in line with the thought of Anthony Giddens (in Priyono, 2016), regarding the existence of a duality relationship between agency and structure. The agency in this case is represented by IC conditions, and the structure is a rule contained in the basic principles of good corporate governance. So it can be concluded that the existence of agents is still indispensable in the practice of corporate governance in sharia banking.

The weak structure of CG implementation is due to the ratio of actors in this case banking practitioners, in applying good governance due to lack of supervision and the absence of reward and punishment system from the regulator. This can be seen from the provisions of OJK that only require BUS to report 
the implementation of good governance by self assessment. The self-assessment reporting requirements result in a decrease in the control function of the supervisor $(\mathrm{OJK})$, thus resulting in high BUS subjectivity in assessing its own condition. This resulted in the structures formed from the recurring sedimentation of bad governance practices that will over time become the next bad practice tool.

\section{Situation of Problematic Governance and Intellectual Capital of Sharia Banking}

The results of situational analysis of this study reveal four important issues related to the expectations of sharia banking practitioners on the implementation of Islamic banking governance in Indonesia. The first important issue is the sharia governance framework model (SGF-Model) which is in accordance with the situation and condition of sharia banking industry in Indonesia, it is very necessary to be developed soon.

Although BI and OJK already have regulations governing the implementation of corporate governance, according to respondents, the regulation is still inadequate and needs improvement. This is reflected from $43.6 \%$ of respondents stated that OJK does not have adequate sharia governance framework model as a reference of the implementation of corporate governance. Even $93.2 \%$ of respondents expect regulators to set up a sharia governance framework model (SGF-Model). Respondents believe that SGF is very important and a distinction between Sharia banks and conventional banks and a reference to the implementation of a comprehensive governance model for sharia banking.

The second issue, sharia banking must optimize the conditions of intellectual capital. In the knowledge-driven economy era and in line with the rapid development of technology-based financial business model, the development of intellectual capital-based enterprise becomes very important and priority. Respondents' reactions show that $78.6 \%$ of respondents believe that in the development of the financial industry-based economic era, intellectual capital is more important than capital in the form of money or physical (financial \& physical capital), only $5.2 \%$ of respondents disagree and $16,2 \%$ did not give an opinion.

Third, it is necessary to strengthen the main duties and 
functions of the Sharia Supervisory Board (DPS) so that it can perform a strategic role in the corporate governance system. The lack of role of DPS is reflected from $39.3 \%$ of respondents felt that the presence of DPS in the Islamic banking governance system has not protected the interests of stakeholders.

Fourthly, moral and ethics are absolutely used as a precondition of the implementation of Islamic banking governance. Moral and ethical issues become important, as reflected by $29.9 \%$ of respondents are still doubtful that sharia banking opportunities have internal fraud problems smaller than conventional banks, this is supported also by $26.5 \%$ of respondents who disagree and strongly disagree if internal opportunities fraud in sharia banking is smaller than conventional banking. These data show that moral and ethical issues are universal in both sharia and conventional banking. This is in accordance with Efendi (2016) opinion that values, ethics and morale can be embodied in the code of conduct as part of corporate culture that will strengthen the implementation of corporate governance.

\section{Proposed Intellectual Capital Approach for Sharia Corporate Governance}

Sharia banking governance system in Indonesia lags behind compared to Malaysia. Bank Negara Malaysia (BNM) as Malaysia's central bank has developed a corporate governance system that not only makes the implementation of sharia banking governance in Malaysia better, but Syariah banking in Malaysia is able to compete in the global Islamic finance market.

According to Omar et al. (2014), in 2010 BNM has introduced a new set of rules such as the implementation of shariah governance structure known as sharia governance framework 2010 (SGF). In just one year, the implementation of SGF 2010 has been effective in Syariah banking in Malaysia (Omar et al., 2014).

Implementation of Islamic banking governance system in Indonesia does not have a solid foundation, although OJK and BI already have a set of rules on the governance of sharia banking. This is reflected in the fact that, although $37.7 \%$ of respondents stated that the current OJK governance rules are adequate, a large number of respondents (43.6\%) stated that OJK does not have adequate sharia governance framework model as a reference for the implementation of manage the company in detail for sharia 
banks in accordance with POJK No.8/POJK.03/2014.

Based on the results of the questionnaire and CG implementation, there is a gap between the expectations of sharia banking practitioners and the latest real conditions related to the implementation of CG BUS. The real condition of CG BUS implementation has not yet described the actual condition. As a result, stakeholders find it difficult to objectively assess how the actual conditions of CG implementation in sharia banks are.

Although the IC condition of sharia banks is good and significantly influences the performance but most of BUS still focus on human capital development and equate the term human capital with intellectual capital. Whereas human capital is only one component of IC, there are still two other important IC components, namely structure capital and relational capital. It is evident that from 2010 to 2016, none of the BUS in its annual financial statements write the word intellectual capital, BUS just write the word human capital or human resources. Setianto and Sukmana research (2016) also proves that the condition of sharia banking IC in Indonesia has lower IC score than sharia banking in Malaysia.

Related to the gap between the expectations of sharia banking practitioners with the real situation of IC implementation and CG conditions, this study offers enrichment and development of the concept of governance implementation for sharia banking, by incorporating the concept of corporate governance and intellectual capital to establish Islamic governance. The intellectual capital-based corporate governance system for sharia banking will be assembled within the framework as shown in Figure 2.

Figure 2 Framework of CG model base on IC approach
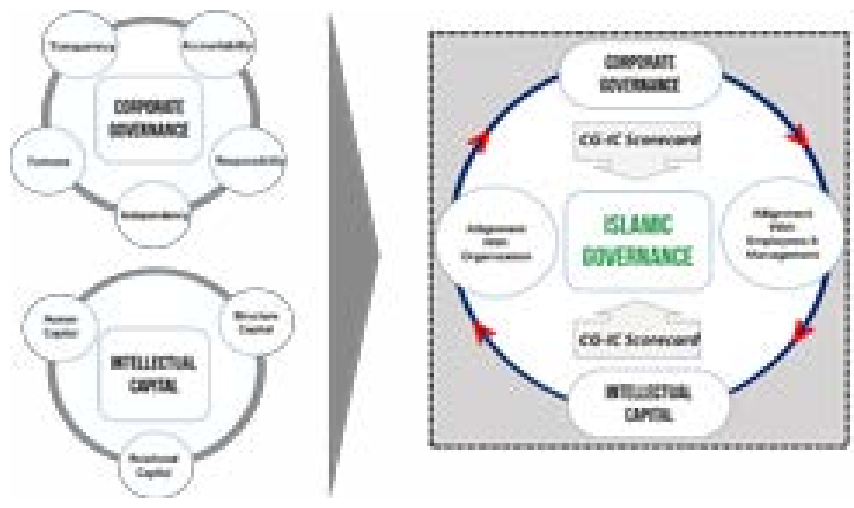
The model that will be developed is to utilize the uniqueness of sharia banking as a supporter of CG and IC application, which is then transformed to produce a system of corporate governance based on the uniqueness of the concept of sharia. The incorporation of CG and IC concepts is a new approach that synergizes to improve Sharia banking performance. According to Keenan (2001), the value of the company will be higher because the governance system uses as well as the financial strength, physical-plant and intellectual capital to create and enhance the value of the company.

The Proposed concept that will be developed refers to the basic principles of the implementation of governance is transparency, accountability, responsibility, independency, and fairness. The basic principles of this CG will transform into sharia corporate governance (SCG). Similarly, intellectual capital consisting of human capital, capital structure and relational capital, will transform into sharia intellectual capital (SIC). SCG and SIC will be aligned with organizations, management and employees to form Islamic Governance as core values and basic guidelines for the implementation of corporate governance model base on intellectual capital

SCG and SIC were developed by weighting SCG and SIC scorecard models or so-called CG-IC Score cards. Unlike the VAIC TM model that uses only quantitative data from financial statements, the weighting of CG-IC Score cards uses a combined approach of quantitative and qualitative. Quantitative data is obtained from certain items of balance sheet and profit and loss. Furthermore, qualitative data obtained from the information and data provided by the company on the annual report and other sources of information related to the definition of each CG and IC operational variables.

The developed model is a derivative of Rampersad's thought (2014). According to Rampersad and Hussain (2014), sustainable corporate governance begins with individual integrity. The intellectual capital-based governance model promotes the personal integrity of employees and company management. Development of integrity is done by increasing the company's attention to the condition of intellectual capital. Ongoing corporate governance will be obtained when sharia banks can align their personal integrity with the integrity of the organization. 
In the era of knowledge-base economy has been identified that the success of a company depends on the company's ability to create the uniqueness of intangible assets and convert them into value for the company (Andriessen, 2001). Intellectual capital is intangible that holds the potential to drive the organization of the company. Intellectual capital can shape the attitudes and personalities of the individuals within the company. While governance, according to Moeljono (2006), focus on the physical and behavior based on the rules of a company.

The idea of developing an intellectual capital-based governance model is in the context of ensuring effective implementation of corporate governance in sharia banking and for all employees and corporate management to be more professional, benefiting the environment and building sustainable competitive advantage.

\section{CONCLUSIONS}

The findings of this study indicate that the intellectual capital of Sharia Commercial Banks in Indonesia contributes significantly to company performance, but the implementation of corporate governance does not contribute significantly to the performance of BUS in the period of 2016. However, CG and IC contribute simultaneously to the performance of BUS. These results indicate that the method of applying the governance of sharia banks is still an agency that emphasizes the importance of personal roles, and demonstrates that the role of the governance system has not worked well. Other points also indicate that the self-assessment CG reporting model is highly subjective and does not adequately describe the actual conditions.

The CG implementation model based on the expectations of sharia banking practitioners indicates that sharia banking needs enrichment and development of a comprehensive sharia governance framework system as a reference for good corporate governance practices for BUS. Corporate governance model based on intellectual capital can be an alternative to be developed in sharia banking industry. Assessment of CG and IC comprehensively can use CGIC-scorecard model. This model in addition to improving the accuracy of the assessment of the implementation of intellectual capital-based governance, also can improve the value and competitiveness of sharia banks to be better to compete in the Asean and global markets. 
This study can provide an input to $\mathrm{BI}$ and OJK as regulator that the provision of self-governance implementation conducted by BUS today is not in accordance with the development and operational complexity of sharia banking industry. To obtain a more comprehensive governance model, further research can be undertaken using more precise methods and broader samples. 


\section{REFERENCES}

Andriessen D. (2001). Weightless Wealth: Four Modifications to Standard IC Theory. Journal of Intellectual Capital, Vol. 2 Iss 3 pp. $204-214$

Andriessen D. (2004). Reconciling the Rigor-relevance Dilemma in Intellectual Capital Research. The Learning Organization, Vol. 11 Iss $4 / 5$ pp. $393-401$

Arifin J. (2016). Corporate Governance and Intellectual Capital on Financial Performance of Bank Sector Companies: Indonesia Stock Exchange 2008-2012. Journal of Administrative Sciences and Policy Studies. Vol (1), 61-82

Bouheni FB, Ammi C and Levy A. (2016). Banking Governance, Performance and Risk-taking. ISTE Ltd. London-UK.

Bratianu, C. (2008). A Dynamic Structure of the Organizational Intellectual capital. In Naaranoja, M (ed) Knowledge manajemen in organization. 222-243

Carrell J. (2007). Intellectual Capital: An Inquiry Into Its Acceptance. Business Renaissance Quarterly. 2(1), 67-69.

Carlucci D, Lerro A. (2010). Foreword: Investigating the Role of Intellectual Capital in today's Business Landscape. Measuring Business Excellence. Vol. 14 Iss 4 pp. 3 - 10

Chen et al. (2014). Rethingking Bank Business Models: The Role of Intangibles. Accounting, Auditing \& Accountability Journal. 27(3). 563-589

Dusuki A.W. (2006). Corporate Governance and Stakeholder Management of Islamic Financial Institutions. National Seminar in Islamic Banking and Finance. Nilai.

Earnest DF, Sofian S. (2013). The Mediating Role of Corporate Governance on Intellectual Capital and Corporate performance. Journal of Economics, Business and Management. 1(4)

Edvinsson L and Malone M. (1997). Intellectual Capital: Realizing your company's True Value by Findings its Hiden Brainpower. HarperCollins. NewYork 
Hidalgo RL, Garcia-Meca E, Martinez I. (2011). Corporate Governance and Intellectual Capital Disclosure. Journal of Business Ethics. Vol.100, 483-495.

Holland J. (2003). Intellectual Capital and the Capital Marketorganization and Competence. Accounting, Auditing $\mathcal{E}$ Accountability Journal. Ch.5

Haniffa TNR. (2017). Determinants of Financial Performance of Islamic Banks: an Intellectual Capital Perspective. Journal of Islamic Accounting and Business Research. Vol. 8 Iss 2.

Kamukama N, Ahiauzu A and Ntayi JM. (2011). Competitive Advantage: Mediator of Intellectual Capital and Performance. Journal of Intellectual Capital. 12(1), 152-164

Kaplan RS, and Norton DP. (2004). Mastering the Management System. Harvard Business Review. Januari, 62-77

Keenan J and Aggestam M. (2001). Corporate Governance and Intellectual Capital: Some Conceptualisations. Blackwell Publisher Ltd. Vol 9(4)

KNKG. (2011). Pedoman Umum Good Corparate Governance Bisnis Syariah. Diterbitkan oleh Komite Nasional Kebijakan Governance. Jakarta

Lapina OLI. (2016). The Transformation of the Organization's intellectual Capital: from Resource to Capital. Journal of Intellectual Capital. Vol. 17 Iss 4.

Lessambo FI. (2014). The International Corporate Governance System Audit Roles and Board Oversight. Palgrave Macmillan. Macmillan Publishers Limited. England

Levy A. (2012). Islamic Finance, Toward a Humanist Finance. Gualino Lextenso Editions.

Lukviarman N. (2016). Corporate Governance: Menuju Penguatan Konseptual dan Implementasi di Indonesia. Adicitra Intermedia. Solo. Indonesia 
Mallin CA. (2013). Corporate Governance. Oxford University Press. United Kingdom

Meritum. (2002). Guidelines for Managing and Reporting on Intangibles Intellectual Capital Report, TSER Programme. Meritum Tucson, AZ

Mishra S, Mohanty B. (2014). Corporate Governance as a Value Driver for Firm Performance: Evidence from India. Emerald Group Publishing Limited. Vol. 14, No. 2, pp. 265-280.

Moeljono D. (2006). Good Corporate Culture Sebagai Inti Dari Good Corporate Governance. Jakarta. Elex Media Komputindo Kelompok Gramedia.

Moore L, Craig L. (2008). Intellectual in Enterprise Success. Published by John Wiley \& Sons, Inc., Hoboken, New Jersey.

Ocean Tomo. (2015). Components of SEP 500 Market Value. Ocean Tomo LLC, The Intellectual Capital Merchan Banc

OJK. (2017). Statistik Perbankan Tahun 2017. Otoritas Jasa Keuangan. Jakarta

Omar MN et al. (2014). The Implementation of Sharia Governance Framework of 2010: Advantage and Contraints. Australian Journal of Basic and Applied Science. 8(3), 684-687.

Priyono BH. (2016). Anthony Giddens Suatu Pengantar. Jakarta. Kepustakaan Populer Gramedia (KPG).

Pulic A. (1998). Basic Information on VAIC. Available online at www.vaic.net.

Rampersad H, Hussain S. (2014). Authentic Governance: Aligning Personal Governance with Corporate Governance. Springer International Publishing Switzerland

Riduan, Kuncoro EA. (2008). Cara Menggunakan dan Memaknai Analisis Jalur. Penerbit Alfabeta Bandung

Saffiedine A, Jamali D dan Noureddine S. (2009). Corporate Governance and Intellectual Capital: Evidence from an Academic 
Institution. Corporate Governance. Vol 9(2)

Santoso E. (2011). Intellectual Capital in Indonesia: The Influence on Financial Performance of Banking Industry. Dissertation University of Phoenix

Setianto RH, Sukmana R. (2016). Intellectual Capital and Islamic Bank's Performance: Evidence from Indonesia and Malaysia. Iqtishadia 9(2), 376-397. DOI: http://dx.doi.org/10.21043/ iqtishadia.v9i2.

Shiu HJ. (2006). The Application of the Value Added Intellectual Coefficient to Measure Coporate Performance: Evidence from Tchnological Firm. Internnational Journal of Management. 23(2), pp 356-356.

Shih KH, Chang CJ dan Lin B. (2010) Assessing Knowledge Creation and Intellectual Capital in banking Industry. Journal of Intellectual Capital. !!(1), 74-89

Shleifer A, Vishny RW. (1997). A Survey of Corporate Governance. Journal of Finance. vol. 52, pp. 737-783.

Sveiby, EK. (1997).The New Organizational Wealth. Managing $\mathcal{E}$ Measuring Knowledge-based Assets. San Fransisco: Berret-Koehler Publisher, Inc. USA

TechCrunch-Wallstreet Journal. (2016). Available online at www. techcrunch.com/2016/08/04/indonesias-go-jek-raises550-million-to-battle-uber-and-grab/

Ulum I. (2013). iB-VAIC: Model Pengukuran kinerja Intellectual Capital Perbankan Syariah di Indonesia. Jurnal Inferensi, 7(1), 183-204

Wang, JC. (2008). Investigating Market Value and Intellectual Capital for S\&P 500. Journal of Intellectual Capital. 9(4). 546-563

Yalwee AH, Buscemi A. (2014). An era of Intangible Assets. Journal of Applied Finance \& Banking. 4(5), 17-26 